\title{
A FUNCTIONALIST ACCOUNT OF HUMAN UNIQUENESS
}

\author{
Anthony Bolos
}

\begin{abstract}
I challenge the assumption that human uniqueness of the sort motivated by the doctrine of the imago Dei is incompatible with contemporary views in evolutionary biology. I first develop a functionalist account of the image of God and then argue that image bearing is a contingently imposed function. Humans, chosen by God to bear his image, are unique in that they alone possess an ideal range of image bearing capacities. This ideal range makes humans well-suited for the role of image bearing.
\end{abstract}

\section{Introduction}

In this paper I make two assumptions. First, I assume that humans are God's image bearers. ${ }^{1}$ Second, I assume that contemporary views in evolutionary biology are true. ${ }^{2}$ Assuming both to be true, however, presents an important challenge. The challenge, roughly, is to "explain-or even merely to describe - the special nature of humankind in the face of evolutionary science." ${ }^{3}$ Call this the problem of human uniqueness. The tension arises when we consider what it means to be both an image bearer and a member of the Homo sapiens species.

Before describing this tension, let me say something brief about human uniqueness. The creation account in Genesis is often used to motivate the

\footnotetext{
'See Genesis 1:26-27. Note, when referring to "humans" I am referring to anatomically modern humans who are characterized by modern language, abstract thought, and other defining characteristics that separate us from other homo species.

${ }^{2}$ Consider two brief points: First, I do not assume that the theory of evolution is monolithic in the sense that there is one distinct thesis with which contemporary evolutionary theory is concerned. In this essay, though, I am primarily concerned with the relationship between humans being God's image bearers and the idea that humans have evolved, for example, by process of natural selection (among other mechanisms). Second, "the theology of the imago Dei" could be more appropriately phrased "a theology of the imago Dei" given the various interpretations of the passage. The functionalist view I endorse below, though, is widely accepted within contemporary biblical scholarship.
}

${ }^{3}$ Berry, "Did Darwin Dethrone Humankind?," 61. 
idea that humans are unique. ${ }^{4}$ A quick glance at this account reveals that humans are wholly distinct from other animals and specially created by God to bear his image. There is little doubt from the creation story that humans are the pinnacle of the creation story. God, for example, speaks to humans, grants them charge over other parts of the creation, and clearly defines their role on earth. James Rachels puts it this way:

Man is special because he alone is made in the image of God, and above all other creatures he is the object of God's love and attention; the other creatures, which were not made in God's image, were given for man's use. ${ }^{5}$

Historically, many assumed that because of this special attention there must be something unique about humans. What is it about humans, then, that makes them distinct or qualitatively different from other species? Roughly, humans are thought to possess traits which other species lack. Many have thought that reason, for example, is what separates humans from other animals. Or perhaps it is the ability of humans to develop a special relationship with God which makes them unique. Whatever the reason, the special nature or uniqueness of humans is, then, measured by a real qualitative difference.

What, then, is the problem with human uniqueness on the evolutionary account? Briefly, the worry is that the story of evolution only allows for a difference of degree between humans and non-humans. As Charles Darwin famously said, "The difference in mind between man and the higher animals, great as it is, certainly is one of degree and not of kind." 6 If this is the case, there is no qualitative difference as is often assumed and humans do not possess a distinctive kind of intelligence. Now, this point might be hard to see when comparing humans to caterpillars. But when comparing humans to chimpanzees, Darwin's point becomes more interesting. In ordinary language, we even speak as if these differences are merely a matter degree. We often say, for example, "Humans are more intelligent than apes" or "Apes are much stronger than humans." This point is further illustrated when considering now extinct hominids who were much closer to modern humans than any living ape. These now extinct hominids used sophisticated tools, created music, technology, and art, which are all things we typically only attribute to the modern human. ${ }^{7}$ But none of these other creatures are thought to be image bearers, despite

${ }^{4}$ Human uniqueness is sometimes expressed in terms of value. The traits (or capacities) which humans possess are sometimes thought to reflect the nature of God. This is what gives humans value over and above other creatures. It is thought, then, that humans are intrinsically valuable in a way that other creatures are not. I am not, though, thinking of value in these terms and offer a different account below. For an excellent discussion on value see Matchulat, "Rationality and Human Value." See also Adams, Finite and Infinite Goods. For a rejection of human uniqueness and value see Joshua Moritz, "Evolution."

${ }^{5}$ Rachels, Created from Animals, 87.

${ }^{6}$ Darwin, The Descent of Man, 151.

${ }^{7}$ See Sawyer et al., The Last Human. 
some impressive similarities between us. This leads Moritz to argue the following:

Given the physical resemblance and behavioural similarities of these extinct hominids to modern humans, we must curtail any aspirations we might have to name one or a few unique characteristics that elevate Homo sapiens above and beyond all other creatures. ${ }^{8}$

The above points are important in this context. Given, at the very least, the capacities of early hominids, it appears that humans are not unique. And it's plausible to assume that these differences really amount to degree, as Darwin suggests. There is another point, though, that should be addressed. Setting aside the problem of early hominids, it's not clear that human uniqueness can be motivated regarding more distant species either. Often, human traits are thought to be "higher" or "better" and, at times, human uniqueness is motived by noting this distinction between species. ${ }^{9}$ Palaeontologist G. G. Simpson captures this sentiment well: "Man is an entirely new kind of animal in ways altogether fundamental for understanding of his nature. . . Man is the highest animal." ${ }^{10}$ The problem with this thinking, though, is that although the appearance of humans in Genesis represents something special in the creation narrative, the appearance of humans on the evolutionary timeline does not entail this. As Alex Rosenberg and Daniel W. McShea note, the Darwinian view is that "modern humans are not higher than modern worms. Both occupy the tips of the youngest twigs on a branching evolutionary bush, both have been evolving for the same amount of time, and therefore in a sense both are equally advanced." ${ }^{11}$ Going further, they claim that modern biology is "thoroughly Darwinian" in this regard. ${ }^{12}$ The idea here is that all surviving species, whether it be modern worms or modern humans, possess traits which are no "better" or "higher" than other creatures which have evolved. The reason for this is that all creatures, regardless of capacities, are aiming at the same thing: survival and reproduction. In other words, our traits have enabled us to do precisely what all living species excel at, namely, survival and reproduction. We are, in the end, all too similar to other animals. ${ }^{13}$

\footnotetext{
${ }^{8}$ Moritz, "Evolution," 317.

${ }^{9}$ Again, this is sometimes thought of in terms of value.

${ }^{10}$ Simpson, Meaning of Evolution, 284-285.

${ }^{11}$ Rosenberg and McShea, Philosophy of Biology, 127.

${ }^{12}$ In other words, this position is central to modern biology.

${ }^{13}$ There is an objection regarding evolutionary progress which should be noted. For example, it seems that species do make progress through evolutionary change. And this progress is for the betterment of the species. If this is the case, then it might look like certain traits are in fact more valuable. This is a very complex issue and one that I'm going to set aside for this paper. See Darwin, On the Origin of Species, 309. Also, note that if one objects to the claims regarding uniqueness, the argument can be seen as a conditional one. Thus, even if we grant the claim that the differences between species are a matter of degree, there is still a way to account for human uniqueness.
} 
Summarizing what we've said so far, here is how the argument against human uniqueness is put:

(1) If the doctrine of the image of God is true, then humans are unique.

(2) If evolution is true, then humans are not unique.

(3) Evolution is true.

(4) Therefore, humans are not unique. [2,3]

(5) Therefore, the doctrine of the image of God is false. [1, 4]

One solution to this argument is to simply reject (1). ${ }^{14}$ By rejecting (1), both evolution and the doctrine of the image God can be held simultaneously without any conflict. Rejecting (1), though, comes at a significant cost. First, there is strong textual evidence from the creation account which points to the uniqueness of humans. Second, there is a rich tradition of understanding the text in exactly this way. So not only would you be rejecting what seems to be the most obvious interpretation, you are also rejecting centuries of theological tradition regarding the Genesis narrative. And whenever possible, I think, we should work hard to maintain this tradition. I will argue, then, that (2) is false.

How, then, can we motivate the idea that humans are unique? First, I begin describing the most influential contemporary account of the image of God: the functionalist view. ${ }^{15}$ The functionalist view, roughly, argues that humans are called to be God's representative here on earth. ${ }^{16}$ I then argue that the function of representing God is imposed contingently by God. Being human, then, does not necessarily entail being an image bearer. ${ }^{17}$ In other words, this ambassadorial role is something humans are elected or appointed to and not necessarily something they are in virtue of being a human. I then explain why humans are suitable for this role. ${ }^{18}$ They are suitable because they fall within the ideal range of image bearing properties and this, in the end, makes them uniquely equipped for this role. This, I believe, accounts for the special nature of humans.

\section{The Image of God: A Functionalist Account}

There is no shortage of contemporary literature on the interpretation of Genesis 1:26-28. As Phyllis Bird notes, "Literature on the passage is now

\footnotetext{
${ }^{14}$ See Moritz, "Evolution."

${ }^{15}$ As James Barr notes in his Gifford Lectures, the functional view is "doubtless the most influential opinion today" (Barr, Biblical Faith and Natural Theology, 158). Others claim that the functionalist view has "come to virtually monopolize" Old Testament scholarship (Middleton, The Liberating Image, 29).

${ }^{16}$ We are, in other words, God's ambassadors or vice-regents.

${ }^{17}$ Some have argued, though, that the image is necessary and not contingent: "To be human and to be the image of God are not separable" (Clines, "The Image of God in Man," 101).

${ }^{18}$ One way to think about this is to ask why, of all the creatures that have evolved, are humans God's image bearers?
} 
boundless" and "shows no sign of ceasing or abating."19 Adding to this "boundless" literature, of course, are the ideas of the patristic, medieval, and reformation writers, all of whom provide important insights into the nature of the image of God. Sometimes called the substantive view, many of these writers argue that the image of God is directly related to our ability as humans to reason. David Cairns notes that "in all the Christian writers up to Aquinas we find the image of God conceived as man's power of reason." ${ }^{20}$ Despite their uniformity, though, there are some interesting differences. Irenaeus, for example, argued that image and likeness represented two different facets of human nature that are linked to the image of God, with the latter being lost at the fall. ${ }^{21}$ And while Irenaeus does give priority to reason, he also stresses the importance of freedom and the physical nature of man. Augustine famously argues that the image of God was somehow related to the trinity, with the image consisting as a trinity in man-memoria, intellectus, and amor..$^{22}$ And while Aquinas upheld the tradition of seeing reason as essential to the image, he further argues that more rational creatures will bear more of the image of God. ${ }^{23}$ With the reformers, however, there is a slight shift away from the substantive view. Luther and Calvin, while not fully abandoning the substantive view, defended what they saw as both an Old Testament image and a New Testament image - the former being related to man's original righteousness and the latter to his restoration. ${ }^{24}$ So while Calvin, for example, found the image of God in the soul and believed the image to be related to knowledge, there was an important relational aspect as well. Being in right relationship to God was essential to image bearing and was hopelessly hindered by the fall and thus in need of restoration. ${ }^{25}$

Despite the appeal of the substantive view, there are, at present, two dominant interpretations of Genesis 1:26-28: the functional view and the Barthian-relational view (so called because of Karl Barth's influential exegesis of Genesis 1:27). ${ }^{26}$ The functional view argues that to be God's image bearer is to be his vice-regent or representative here on earth (more on this below). The relational view argues that to be an image bearer is to have the ability, as humans, to enter a relationship with God. While biblical scholars largely favor the functional interpretation, the Barthian-relational

\footnotetext{
${ }^{19}$ Bird, "Male and Female He Created Them," 129.

${ }^{20}$ Cairns, The Image of God in Man, 110.

${ }^{21}$ Irenaeus, Against Heresies, V.6.1.

${ }^{22}$ Augustine, De Trinitate, 8.

${ }^{23}$ Aquinas, Summa Theologica, I.93.2-I.93.10.

${ }^{24}$ Even though both Luther and Calvin incorporated a relational aspect, Karl Barth lumped the Reformers together with the medieval view of the image. See Barth, Church Dogmatics, v.3.1.

${ }^{25}$ Calvin, Institutes of the Christian Religion, I.15.3. For a nice overview of Calvin's position, see Hoekema, Created in God's Image, 42-49. For a different treatment of the reformed position, see Berkouwer, Man: The Image of God.

${ }^{26}$ Barth, Church Dogmatics, v3.1.
} 
view is still popular with some theologians. ${ }^{27} \mathrm{~A}$ detailed look at these competing interpretations is beyond the scope of this paper. ${ }^{28} \mathrm{My}$ aim here is to provide an account of human uniqueness within the functionalist interpretation..$^{29}$

The reason for my focus on the functionalist view is not only its popularity, but also because there is compelling evidence for it. Consider first the royal language of the Genesis text. ${ }^{30}$ In Genesis 1:26-28, God's image bearers are called to rule over creation and subdue the earth. Throughout the Old Testament these types of commands (ruling and subduing) are often seen as royal functions in that they are specially reserved for kings and rulers. ${ }^{31}$ Thus, in using this royal language for God's image bearers, the author is noting that the role of humans on earth is primarily functional or missional. But what exactly is this function? It is, put simply, to represent God on earth. In representing God, humans both image God and are like him. God, the sovereign ruler of the cosmos, creates humans who will rule on earth. Put another way, "humanity is like this God, with the special role of representing or imaging God's rule in this world." ${ }^{32}$ This view, that humans have the function of representing God, is further motivated by the parallels between the Genesis narrative and other relevant ancient Near East (ANE) literature. To begin, the use of "image and likeness" in Genesis 1:26-27 was not uncommon in the ANE literature and, as Middleton notes, "in some Mesopotamian examples the word used for 'image' is precisely the Akkadian cognate of the Hebrew selem." 33 This connection is important to the functionalist view given the way in which this imagery (the imagery of being "in the image and likeness" of God) is understood in the ANE. A commonly cited example from the ANE draws on similarities between kings and the statues they would erect of themselves in foreign lands. Kings, for example, would often set up images (e.g., statues) of themselves in lands where they, despite their rule, were physically absent. The authority of the ruling king was established by reminding the subjects,

${ }^{27}$ See Bird, "Male and Female He Created Them," 129. For a recent exegetical defense of Barth's view by an Old Testament scholar see McDonald, "The Imago Dei and Election."

${ }^{28}$ For an overview see Middleton, The Liberating Image, 15-42.

${ }^{29}$ These competing views are not mutually exclusive. As will become evident below, part of fulfilling the role of God's representative involves the ability to enter a meaningful relationship with God. So, while I am committed to the functional view, much of what is argued here could also be applied to the relational view of the imago Dei. Also, I should note something about the substantive view mentioned above. While I reject (for exegetical reasons) the medieval view that the image implies similarity to God's nature (e.g., reason), I do make use of the substantive view. There is, I think, something important about rationality (and form) as it relates to the image of God. Augustine and Aquinas, I believe, get this intuition right. The difference, of course, is that I see these features as essential only in terms of function. This will, I hope, become clear as the paper goes on.

${ }^{30}$ See Anderson, "A Stylistic Study of the Priestly Creation Story."

${ }^{31}$ For more on this see Stek, "What Says the Scripture?"

${ }^{32}$ Middleton, The Liberating Image, 26.

${ }^{33}$ Middleton, The Liberating Image, 27. For more on ancient Near East literature and usages of Hebrew word selem see Bird, "Male and Female He Created Them," 138. 
through this image, who was in control. The parallels here should be clear. Humans are the image of God in the sense that they are the physical representation of an invisible deity. Gehard von Rad famously puts it thus:

Just as powerful earthly kings, to indicate their claim to dominion, erect an image of themselves in the provinces of their empire where they do not personally appear, so man is placed upon earth in God's image as God's sovereign emblem. He is really only God's representative. ${ }^{34}$

There is another important parallel that should be noted. This one, I think, is particularly compelling for the functionalist interpretation. Instead of kings merely setting up images (e.g., statues) of themselves in faraway lands, kings (and priests) in some ANE literature were said to be the image or likeness of their deity. Note, they themselves were not necessarily divine, but were thought to be earthly rulers who were divinely appointed by their deities with the function of representing the aims and interests of their gods. ${ }^{35}$ Thus, when these kings or priests would speak or act, it was on behalf of the deities they were representing. It is these parallels, in conjunction with the royal language of Genesis 1, which account for the nearly unanimous agreement amongst biblical scholars regarding the meaning of Genesis 1:26-27.

If the function or mission of humans is to represent God, what does this entail? To get a better idea of what this amounts to, we need to return briefly to the royal language of Genesis 1 where God is creating the world. We noted above the parallels between ANE literature and the biblical concept of the image of God. Another parallel should be noted: kings and priests, ruling from their kingdoms and temples, and God ruling from his temple or kingdom. ${ }^{36}$ When kings build their kingdoms and priests their temples, they are easily identifiable. But where exactly is God's temple? In Genesis 1, God is creating his temple, or, some call it, his cosmic sanctuary. ${ }^{37}$ The earth, for the author of Genesis, is God's temple. And humans are a central part of the temple that God is creating. Humans are central in that they alone are "granted authorized power to share in God's rule or administration of the earth's resource and creatures." ${ }^{38}$ Nahum Sarna illustrates this point further:

[The human is a] symbol of God's presence on earth. While he is not divine, his very existence bears witness to the activity of God in the life of the world. This awareness inevitably entails an awesome responsibility and imposes a code of living that conforms with the consciousness of that fact. ${ }^{39}$

${ }^{34}$ Rad, Genesis: A Commentary, 60. Also, for my purposes "representing" God is synonymous with "mirroring" or "reflecting" God, and I will use them interchangeably.

${ }^{35}$ See Clines, "The Image of God in Man" and Bird, "Male and Female He Created Them."

${ }^{36}$ For our purposes I will use these terms interchangeably.

${ }^{37}$ For a rich discussion on this see Middleton, The Liberating Image, 77-88.

${ }^{38}$ Middleton, The Liberating Image, 27.

${ }^{39}$ Nahum Sarna, JPS Torah Commentary: Genesis, 12. 
Humans, then, have a responsibility to act on behalf of the God they represent. As God's representative they have a duty to fulfill the aims of Gods kingdom and should align their affections with those of the God they represent. Fulfillment here is meant to convey the idea that God's image bearers can aptly and dutifully carry out the tasks that image bearers are expected to perform. These acts might include particular commands that the image bearer is directed to fulfill. In Genesis 1:28, right after humans are said to be image bearers, we are given a glimpse of the expectations: "Be fruitful and multiply and fill the earth and subdue it, and have dominion over the fish of the sea and over the birds of the heavens and over every living thing that moves on the earth." 40 The fulfillment of task-oriented commands, though, are not the only ways in which one fulfills the imago Dei. In other passages, humans are called to lead morally good lives just like the God they represent. ${ }^{41}$ They are, in other words, called to be a certain kind of image bearer. Call the fulfillment of these types of commands "expression-oriented" commands. That God's image bearers have a responsibility to fulfill both task- and expression-oriented commands should not be surprising given the picture of representation that is being defended thus far. Imagine, for example, a king who sends a representative to a distant land. This role, it seems, comes with certain expectations. One would expect, correctly I think, that the appointed representative be one who not only fulfills the task-oriented commands of the king, but also exemplifies the characteristics or qualities of the king. One way in which the fulfillment of expression plays out practically is that the representative would value (or at least have the ability to value) those virtues which are paramount to the king and his kingdom. Goodness, justice, and love, for example, might be the virtues that a representative would value if the king they represented shared these values. The argument then is this: the privilege of being God's vice-regent on earth comes with certain responsibilities and expectations. And among these expectations is the ability to fulfill the imago Dei. Humans, in the end, represent God in his cosmic sanctuary by fulfilling the expected duties of this role.

With the functionalist view in mind, there is one final point. There is no reason to assume, from an exegetical standpoint, that humans are necessarily image bearers. ${ }^{42}$ It doesn't follow from the text that because humans do in fact bear the image of God that they must bear his image. In fact, the position that humans are only contingently God's image bearers fits well with the functional interpretation. Recall that on the functional view humans fulfill what is sometimes called an ambassadorial role. A natural way to understand this is that the ambassadorial role is something you are

\footnotetext{
${ }^{40} \mathrm{All}$ scripture passages are taken from the English Standard Version.

${ }^{41}$ See, for example, I Peter 1:13-16. Even though "holiness" in this passage is directly concerned with humans being set apart, there are certainly moral ramifications which are relevant.

${ }^{42}$ See n. 7. Also, note that the functionalist account of the image of God is also consistent with humans being necessarily image bearers.
} 
appointed or elected to and not necessarily something you are in virtue of being a human. Applying the royal language of the Genesis narrative, one becomes an ambassador because of skills and abilities which are valued by the king (and this in turn makes you a valuable asset to the kingdom). The idea is that the ambassador has these abilities before being appointed to this role. My understanding of the image bearer is similar in this regard. The declaration of image bearing in Genesis is the announcement of a new role for humans - the beginning of an important relationship between God and humans. And this takes place at a time and point in history when God first revealed himself. ${ }^{43}$ Denis Alexander, writing on the earliest humans mentioned in the Hebrew Scriptures, notes something similar to what I am proposing:

God in his grace chose a couple of Neolithic farmers in the Near East, or maybe a community of farmers, to whom he chose to reveal himself in a special way, calling them into fellowship with himself-so that they might know him as a personal God. It is not that there were no settled farmers beforehand, but from now on here would be a community who would know that they were called to holy enterprise, called to be stewards of God's creation, called to know God personally. It is for this reason that this first couple, or community, have been termed Homo divinus, the divine humans, those who know the one true God, the Adam and Eve of the Genesis account. ${ }^{44}$

God, in the same way that he called out Adam and Eve, made it known that a particular group of the created order were called to represent God here on earth. These modern humans, chosen by God to mirror him on earth, possessed all the skills and abilities which were essential for such a role. Being human, then, does not entail image bearing but is, importantly, only contingently connected with it.

\section{Form as Fulfillment: Falling Within the Ideal Range}

I am challenging the idea that humans, given evolution, are not unique. The case for human uniqueness hinges on the idea that image bearing is a contingently-imposed function, divinely imparted to humans by God. The question, then, is this: Why, of all the creatures which have evolved, did God appoint humans as image bearers? The reason, I argue, is that humans alone possess a set of unique features which makes them ideal image bearers in this environment. These features, when taken together, are both unique to modern humans and essential for image bearing responsibilities. These are, I believe, form and rationality. ${ }^{45}$ And it is the combination of these traits which makes humans the ideal image bearer

\footnotetext{
${ }^{43}$ One could hold that once modern humans had all the appropriate adaptations (including rationality) necessary for image bearing, they became God's image bearers. Thus, any declaration was simply a recognition of what was already the case. Thanks to an anonymous referee at this journal for pointing this out.

${ }^{44}$ Denis Alexander, Creation or Evolution, 236-237.

${ }^{45}$ By "form" I mean corporeal form. "Rationality," as I am using it here, refers to our cognitive abilities as humans (our ability to reason, engage in abstract thought, etc.).
} 
in this environment. If this is true (that form and rationality play an important role in the fulfilling the imago Dei), then there is another important point that will follow - there is a range of image bearing traits which are ideal for the image bearer to possess. This latter point will of course need to be defended. Roughly, I argue that that humans fall within an "ideal range" of image bearing properties and thus meet the conditions that are ideal for God's image bearers. ${ }^{46}$ It is within this ideal range, then, that we discover the uniqueness of humans.

Let's begin by considering what an ideal range of image bearing form looks like. We can divide creatures into two categories: those creatures with ideal form and those creatures who lack ideal form. Those creatures who lack ideal form can be said to have either deficient form or excessive form. So, for example, those creatures who lack certain corporeal features and are thus restricted from fulfilling the imago Dei can be said to have deficient form. And those creatures whose form allows for abilities well beyond any current ones in existence will also lack the ideal range for image bearing. In the end, those creatures who fall within the ideal range, as I am calling it, will have the ideal form to act as God's representative on earth.

Taking these in turn, let's first consider the idea of deficient form. In Genesis, the task-oriented responsibilities that God's representatives are ordered to fulfill are clearly stated: "Be fruitful and multiply and fill the earth and subdue it, and have dominion over the fish of the sea and over the birds of the heavens and over every living thing that moves on the earth." ${ }^{47}$ Now suppose there is a world where God's representatives are blobfish. The creation story in Genesis has remained the same, but instead of God choosing humans as his representatives, the blobfish has been given this honor. True to its name, a blobfish is a gelatinous blob with no muscles. In fact, the blobfish spends most of its time in a stationary position waiting for its prey to float by. And lest some might think this unsightly creature is lazy, it is hardly his fault that he spends most of his time in the same place; after all, the blobfish is seriously restricted by its form. Given this, could one imagine the blobfish being God's representative here on earth? Could the blobfish fulfill the commands that God's image bearers are supposed to fulfill? Could a blobfish, given its current plight of being a gelatinous blob, really have dominion over the rest of creation and be the caretaker or overseer that God intended his image bearers to be? It seems, given what we know about the blobfish, that the answer is rather obvious - the blobfish, given its form, is not capable of fulfilling the responsibilities associated with image bearing.

\footnotetext{
${ }^{46}$ The notion of an ideal range here is similar to Aristotle's hypothetical necessity. An axe, in order to fulfill the function of cutting stone or wood, must possess certain properties. Likewise, humans, in order to fulfill the function of image bearing, must also a possess certain properties. I am grateful to Mark Murphy for this example.

${ }^{47}$ Genesis 1:27-30.
} 
Of course, it is not only the task-oriented responsibilities which the blobfish cannot fulfill. Given its form, the blobfish is also incapable of fulfilling expression-oriented commands. If image bearers represent God by mirroring or reflecting him on earth, then, as noted above, there is an expectation that the image bearer exemplify the characteristics or qualities of the king. To see how deficient form is less than ideal for an image bearer, consider some of the ways in which humans reflect God through their expressions. Humans, like the God whose image they bear, are creative beings. ${ }^{48}$ And in this act of creating, we plan, develop, put together, take apart, etc. Our ability as humans to create varies and is not restricted to some physical category (e.g., building a house). The image, for example, is also expressed through entertainment, paintings, books, ideas (e.g., theological, political, philosophical), poetry, and so on. Humans also mirror God through expressions of love and kindness, whether offering a hug to someone in need or protecting those who are most vulnerable.

It seems clear, then, that corporeal form will play an important role in fulfillment. Even if the blobfish wanted to express the imago Dei-through some action like creating - the possibility of such a desire coming to fruition is unlikely. ${ }^{49}$ Of course, the blobfish isn't alone in this category. There are thousands of other species whose form restricts them from being the ideal image bearer. Thus, when it comes to corporeal form, deficient form, as seen in case of the blobfish, is less than ideal for God's representatives.

I take it that this point will be accepted without much resistance. There is a more difficult point, though, that needs addressing. What about those creatures who exhibit excessive form? What if, for example, humans could jump over mountains? Or better, what if their strength permitted them to pick up and move any mountains that were in their path? Wouldn't these creatures have been just as ideal for God's image bearers? After all, it could be argued that the more capabilities our corporeal form permits the better the representatives would be fulfilling the imago Dei. Now, so far as we know, there aren't any creatures on this planet that have excessive form in the manner described. ${ }^{50}$ But imagine there exists creatures like, for example, Dr. Manhattan. ${ }^{51}$ Dr. Manhattan's form allows him to walk through walls, frequent other galaxies, be in several places at once, and create complex matter without any effort. These creatures, with excessive

\footnotetext{
${ }^{48}$ For an excellent discussion on the relationship between human creativity and the image of God see Watkins, Creativity and Sacrifice, 41-57.

${ }^{49}$ Note the point here isn't that certain creatures couldn't fulfill the image of God in some way. Perhaps the blobfish, if it had the rational capacity, could show love or kindness in its own unique way. The idea, though, is that when compared to humans the range of fulfillment will always be less given its form. And, of course, this assumes that the blobfish has the necessary rational capacities. In the end, the argument will hinge on the notion that representing God requires the perfect balance of image bearing properties.

${ }^{50}$ Note that I am restricting my account to this specific environment.

${ }^{51}$ Dr. Manhattan is a character in the graphic novel Watchmen by Alan Moore. His corporeal form allows him to do extraordinary things well beyond what any human can do.
} 
form similar to that of Dr. Manhattan's, are less than ideal image bearers. I offer two reasons here and then one in the next section. And while they are closely related, each reason could be independent of each other. ${ }^{52}$

First, creatures like Dr. Manhattan are too similar to the image they are bearing. ${ }^{53}$ Dr. Manhattan is, in a sense, too godlike. Image bearers are meant serve as viceroys who act on behalf of a sovereign. Not themselves be sovereign.$^{54}$ Kings who send representatives to far off lands might expect these representatives to fulfill certain duties and express qualities valued by the king, but they do so recognizing that these expressions are just that-expressions which mirror those qualities valued by the king. They are imperfect at best and merely point towards the image they are bearing. There is a clear distinction between the creator and his creation. Image bearers with excessive form distort this important distinction. ${ }^{55}$

Second, if creatures like Dr. Manhattan were God's representatives, then the world would be devoid of a certain kind of value-namely the value of achievements. Let's call an achievement a success from ability. While a detailed discussion into nature and value of achievements is beyond the scope of this paper, a brief look into some of the arguments will serve for our purposes. ${ }^{56}$ First, let's divide achievements into two categories: weak and strong. The latter is what most take to be valuable given the ease with which the former are realized. Consider the following example:

Mount Everest: Edmund and Didier both have a desire to summit Mount Everest. Edmund, who has been training for some time, successfully climbs Mount Everest by starting at the base. Didier, on the other hand, realizes his goal by taking a short and painless helicopter ride to the summit.

\footnotetext{
${ }^{52}$ That each point is independent is important in this context. Some, for example, may find some of the reasons more (or less) compelling than others.

${ }^{53}$ Consider a point of clarification: I am concerned only with those excessive features which interfere unnecessarily with image bearing. It could be that having too much virtue is not a bad thing and would not interfere with image bearing (e.g., love). Thanks to Mark Murphy for pointing this out.

${ }^{54}$ One could note that the gap between God and Dr. Manhattan types is, of course, still infinite. Thus, they are still very different. This is right, though keep in mind that in this environment (here on earth) their ability to easily fulfill the imago Dei is the same. In this regard they are too similar. Moreover, I take it that the task-oriented commands are also fixed. So subduing beasts for Dr. Manhattan requires no effort whatsoever. This is, it seems, too god-like for an image bearer.

${ }^{55} \mathrm{An}$ objection here could be the glorified bodies in the Christian tradition. After death, it seems that humans will have advanced physical capacities. This, to my knowledge, was never seen as a problem. Two points in response. First, the point regarding excessive abilities is in relation to the role as image bearers in this life. It's not at all clear that humans will still serve in this capacity in the afterlife. It's plausible that our service in this role is no longer necessary. Second, it's important to note that the physical form of Dr. Manhattan is, more than likely, way beyond the glorified bodies of humans. Thanks to an anonymous reviewer at this journal for raising this objection.

${ }^{56}$ For a good discussion on achievements and epistemic value see Pritchard, "Knowledge and Final Value."
} 
To begin, it's clear why we value Edmund's achievement here. The effort and ability it takes to realize this goal is something we all recognize as great. Further, the obstacles that Edmund has overcome (fatigue, effects of high altitude, etc.) are also impressive. It's clear, though, that Didier has also achieved something. After all, he did realize his goal by summiting Everest. Perhaps he even demonstrated some skill by selecting a veteran pilot as opposed to a novice. Despite this, the achievements here seem different. The difference between these two types of achievements is that one seems to demonstrate great skill while the other is what we call an easy achievement. ${ }^{57}$ In terms of value, then, it is the strong achievement (the overcoming of obstacles, the demonstration of great skill, etc.) that we are after. ${ }^{58}$ Considering Dr. Manhattan, then, his excessive form does not allow for strong achievements in this environment. Dr. Manhattan has no obstacles to overcome when bearing the image of God. Some of humanities greatest creative achievements, like, for example, landing on the moon, come with little to no effort for Dr. Manhattan. It's plausible that every task-oriented responsibility required of image bearers is no more difficult for Dr. Manhattan than a typical human raising their hand. His excessive abilities do, after all, allow for these possibilities. As a result, a world where God's image bearers have excessive form is a world which lacks a certain kind of value - the value that is derived from strong achievements. ${ }^{59}$

In summary, then, there are two problems related excessive form. First, creatures like Dr. Manhattan are too similar to the image they bear. And second, the world would be devoid of certain kind of value - the value of strong achievements. ${ }^{60}$ Given this, Dr. Manhattan's form is less than ideal for God's image bearers.

\section{Rationality as Fulfillment: Falling Within the Ideal Range}

Just as there is an ideal range of form, there is also an ideal range of rationality for image bearing. Those creatures who lack an ideal range of rationality are either deficient or excessive in their expressions. The points noted above regarding deficient form will apply here as well. Successful image bearing requires, at minimum, an understanding of the responsibilities. Returning to the example noted above, imagine the blobfish is called to be God's representatives. As God's representative, the blobfish

\footnotetext{
${ }^{57}$ Another example of an easy achievement would be raising my arm. In most environments, this would be an easy task. For most, the act of raising their arm is not something the requires great skill.

${ }^{58}$ For more on this, see Duncan Pritchard, "Achievements, Luck, and Value."

${ }^{59}$ It could be that the bar of achievements would just be raised. That's a fair point. But, I take it that the world would have to look very different if this were the case. There would be nothing, on this planet, where we are meant to represent God, for humans to achieve (if we are all like Dr. Manhattan). Achievements are environment relative. And in this environment (e.g., earth), there would be fewer (if any) achievements for Dr. Manhattan.

${ }^{60} \mathrm{Or}$, at the very least, there would be far fewer achievements in the environment where image bearers are serving.
} 
is expected to fulfill the imago Dei through both task-oriented and expression-oriented responsibilities. Given the level of rationality the blobfish has, however, it simply can't fulfill the image bearing responsibilities. The blobfish lacks the reasoning power to understand and process even the most basic commands. Given its deficient rationality, then, the blobfish is a less-than-ideal choice as God's representative on earth.

The above point should, I think, be conceded with little resistance. However, a more thorough discussion regarding excessive rationality is necessary. After all, it could be argued, like above, that stronger cognitive abilities (beyond the ones humans have, for example) are just as ideal for God's representatives. Now, so far as we know, there aren't any creatures on this planet that have excessive cognitive abilities. Imagine, though, that creatures like Dr. Manhattan existed. Like his corporeal form, his cognitive abilities are extreme. He can for example, solve the most complex problems (mathematical, philosophical, etc.) with little to no effort. No question is too complicated, and every intellectual endeavor is met with ease.

Now, some of the arguments listed above could apply here. For example, a Dr.-Manhattan-type creature with excessive cognitive abilities would be too similar to the God they are representing. Also, excessive cognitive abilities would rob the world of a certain kind of value - the value of achievements. There is, though, another worry with excessive rationality. As image bearers, humans are called to be in communion with all of creation. I am interpreting this idea of communion broadly here to include, for example, a dependency on others, vulnerability towards each other, and, importantly, the ability to relate to all of God's creatures (e.g., the ability to relate to the suffering of others). God's image bearers are not called to be isolated or indifferent towards creation, but engaged and caring. ${ }^{6}{ }^{1}$ Excessive rationality, though, could rob God's image bearers of the desire to be in communion with all of creation. Dr. Manhattan-type characters are otherworldly and are thus totally self-sufficient in this environment. ${ }^{62}$ The concerns of everyday life are trivial, just like the inhabitants he is burdened to interact with daily. The creators of Dr. Manhattan's character tap into this notion by creating a character who, while displaying extreme cognitive abilities, is bored with life and those around him. In a telling scene where the Comedian (like Dr. Manhattan, a character in Watchmen) guns down an innocent woman, Dr. Manhattan stands idly by. When Dr. Manhattan is challenged as to why didn't intervene, he is faced with the reality that he has lost touch and simply doesn't care enough about humans. This is a recurring theme in the novel. Dr. Manhattan's cognitive abilities are so extreme that he finds it almost impossible to empathize

\footnotetext{
${ }^{61}$ There is some interesting research regarding the relationship between high levels of intelligence and relationships (e.g., how the former negatively affects the latter). For recent treatment on this topic, see Li and Kanazawa, "Country Roads."

${ }^{62} \mathrm{I}$ again stress the importance of the environmental relativeness of image bearing. The reason is that image bearers are called reflect God here on earth, in his cosmic sanctuary.
} 
with humanity. He displays total indifference towards humans, is wholly uninterested in the affairs of this world, and has little time to develop real relationships. He is an isolated individual who lives and interacts with a creation who craves community. This, in the end, proves too much and Dr. Manhattan leaves this galaxy for one "a little less complicated" (where presumably he will not need to interact with humans).

This is in stark contrast to what humans (God's image bearers) are called to do. God's image bearers should seek to understand this creation, not grow tired or weary in the face of injustice. An image bearer with Dr. Manhattan's cognitive ability makes this function of the image unnecessarily difficult. As a result, then, excessive rationality is less than ideal for God's image bearers. And a robust account of the imago Dei will be one where, I believe, rationality is neither deficient nor excessive. It will, in the end, fall within an ideal range. ${ }^{63}$

\section{$V$. Conclusion: Human Uniqueness and the Story of Evolution}

At the beginning of the essay we set out to describe the way in which humans maintain their uniqueness in the face of evolutionary science. The answer to this question is linked, I believe, to an important question: Why, of all the creatures who have evolved, are humans God's image bearers? Put simply, humans possess an ideal range of both form and rationality which serves them well in the function of image bearing. And in relation to other earthly creatures that have evolved, it is humans alone who uniquely possess the ideal combination of these two qualities. Human uniqueness, then, can be seen in the following way: humans uniquely possess, in perfect balance, the combination of ideal form and ideal rationality. It is the unique ability of humans to serve in this role which sets them apart from other creatures. The difference, then, is not only measured in terms of degree. To see this, consider the following analogy. Suppose you have two objects where the difference is only a matter of weight. Intrinsically, then, the difference might only be measured in terms of degree. Though, if you are looking for a paperweight, only the heavier object will do. This is because only one of them possesses the quality of being a good paperweight. I am arguing for something similar regarding human uniqueness. Within evolution it looks as if our differences are, at times, only a matter of degree. But unlike other creatures that have evolved, only humans possess the qualities necessary to be the ideal image bearer. Humans are, put simply, uniquely equipped and apt to serve as image bearers of God.

\footnotetext{
${ }^{63} \mathrm{I}$ am not assuming there is a necessary tension between extreme cognitive abilities and well-being. I do, however, think there are certain environments where this tension more easily arises. An example might be an environment where all the creatures you are called to serve suffer in ways which are wholly unfamiliar to you. Or, perhaps, an environment where all the creatures you are called to serve have needs and desires which you find utterly trivial. Of course, humans, as God's image bearers, might struggle with these things as well. But not, it seems, to the extent that Dr. Manhattan types do. For these reasons, I take humans to possess a more ideal range of rationality.
} 
Before closing, there are two questions which need to be addressed. First, there is the question of rationality and extinct hominids. Second, there is the question of humans who fall outside the ideal range. I will take these in turn.

\section{V.A. Ideal Range and Extinct Hominids}

One criticism of the above account is that there are certain creatures who do in fact come close to resembling modern humans. Take, for example, now extinct hominids. These extinct hominids possess an ideal range of form and, given my very broad definition of rationality, might also possess a sufficient range of rationality ${ }^{64}$ These early hominids were not, though, image bearers. First, note that what we are really asking is why God would choose modern humans and not, for example, other similar Homo species to represent him on earth. The reason given above (as to why God chose humans) is that humans alone possess the unique range of ideal image bearing capacities. This is true, I think, even when comparing those hominids who are very similar to the modern human. While early hominids did display some cognitive abilities, these abilities were, compared to modern humans, still quite primitive (especially, for example, with regard to language). These primitive features, however few they possessed when compared to the modern human, were not ideal for image bearing. This might mean that certain aspects of the ideal range are to be interpreted very narrowly. In other words, early hominids might have possessed many of the ideal capacities for image bearing, except for language. Their primitive language, though, would put them outside the ideal range. This narrow understanding of the ideal range (at least for certain aspects) should not come as a surprise since representation involves mirroring God. And when mirroring God, especially with regard to fulfilling expression-oriented tasks, the required capacities do indeed seem very narrow.

Let's look at a concrete case of an early hominid: Neanderthals. Neanderthals, while certainly possessing an ideal range of form, lacked certain features which make them less-than-ideal image bearers. They lacked, for example, the language abilities of modern humans. ${ }^{65}$ And this, as noted above, is essential for fulfilling both task-oriented and expression-oriented commands. Our ability as humans to develop and complete complex projects depends, to some extent, on our ability to communicate effectively ${ }^{66}$ The sorts of things that humans achieve are due, in part, to our advanced language skills. Further, it was also the lack of certain abilities which led

\footnotetext{
${ }^{64}$ Above, I define rationality only as it pertains to our cognitive abilities as humans (our ability to reason, engage in abstract thought, sophisticated language, etc.). There is an interesting debate here regarding first and second order rationality. For a nice overview, see Matchulat, "Rationality and Human Value," 407-412. Also, see Geach, Truth and Hope, 17-23.

${ }^{65}$ The language abilities of Neanderthals (and other homo species) is one of constant debate. See Benítez-Burraco and Barceló-Coblijn, "Paleogenomics."
}

${ }^{66}$ For the role of language in human evolution see Morgan et al., "Experimental Evidence." 
to their extinction. They simply could not compete for resources with modern humans. They were not, in the end, well-equipped for survival in their own environment. ${ }^{67}$ Thus, for the same reasons that lions, blobfish, and the highland cow lack the sufficient capacities for ideal image bearing, so then did these early hominids. Of course, compared to those creatures just mentioned, it's clear that extinct hominids are far better candidates for image bearers. This is right. But when compared to humans in this environment, these early hominids were not chosen to image God because they lacked some important feature of image bearing.

\section{V.B. Humans Outside the Ideal Range}

If humans are God's image bearers because they are well suited to image God, then what of those humans who fall outside the ideal range? There are humans with severe disabilities, both cognitively and corporeally, who cannot, because of these disabilities, fulfill the image of God in the ways described above. It would be incorrect, I think, to only assume that those with no disabilities image God.

First, note that this is a problem for all accounts of the image of God. The medieval theologians who tied the image directly to rationality must also account for those with disabilities. The relational account is not off the hook either. Those who do not have the cognitive abilities to enter meaningful relationships cannot bear God's image. And while this is also a problem for the functionalist account, it is well positioned to answer this objection. In the Genesis narrative, it's clear that humans, as a species, are designated as God's image bearers. And most biblical scholars have interpreted the text in just this way. In other words, the election of humans to this ambassadorial role is corporate. Humans, as a species, are a community of image bearers whose traits enable them to fulfill the image of God in ways which other creatures cannot. Thus, when humans were given the role of representing God, it was not based on the individual capacities of each human but on the usual capacities of the collective species. Humans do, for the most part, fall within the ideal range described above. Thus, given the corporate nature of this election, even those humans who fall outside the ideal range of image bearing capacities still image God. They bear the mark of election in the same way as those do fall within the ideal range. ${ }^{68}$

In conclusion, some might resist contemporary views in evolutionary biology for philosophical and theological reasons. As it relates to the image of God, the worry is that evolution challenges the long-standing tradition of human uniqueness. The primary aim of this paper, then, is to alleviate this worry and show that it is reasonable to embrace both human uniqueness and contemporary science. Removing this obstacle is,

\footnotetext{
${ }^{67}$ Image bearers should be, on the other hand, well equipped to live and rule in this environment. See Stewart and Stringer, "Human Evolution Out of Africa."

${ }^{68} \mathrm{Further}$, humans with disabilities still have an active role in imaging God, for example by directly mirroring God through their loving interactions with others.
} 
I think, an important step for those who wish to retain the rich theological tradition of the text while also staying true to important discoveries in contemporary science. ${ }^{69}$

\section{Virginia Commonwealth University}

\section{References}

Adams, Robert M. 1999. Finite and Infinite Goods (Oxford University Press).

Alexander, Denis. 2008. Creation or Evolution (Monarch Books).

Anderson, Bernhard W. 1977. "A Stylistic Study of the Priestly Creation Story." In Canon and Authority, edited by George Coats and Burke Long (Fortress Press), $148-162$.

Aquinas, Thomas. 1969. Summa Theologiae. Edited by Thomas Gilby (Image Books). Augustine. 2002. On the Trinity [De Trinitate], Books 8-15. Edited by Gareth B. Matthews, translated by Stephen McKenna (Cambridge University Press).

Barr, James. 1993. Biblical Faith and Natural Theology (Clarendon Press).

Barth, Karl. 1977. Church Dogmatics. Translated by G. T. Thomson (T. \& T. Clark). Benítez-Burraco, Antonio, and Lluís Barceló-Coblijn. 2013. "Paleogenomics, Hominin Interbreeding and Language Evolution." Journal of Anthropological Sciences 91: 239-244. https://doi.org/10.4436/jass.91012

Berkouwer, G. C. 1962. Man: The Image of God (Eerdmans).

Berry, R. J. 2009. “Did Darwin Dethrone Humankind?" In Darwin, Creation, and the Fall, edited by R. J. Berry and T. A. Noble (Inter-Varsity Press), 30-74.

Bird, Phyllis A. 1981. "Male and Female He Created Them." Harvard Theological Review 74: 129-160. https://doi.org/10.1017/S0017816000030558

Cairns, David. 1953. The Image of God in Man (SCM Press).

Calvin, John. 2006. Institutes of the Christian Religion. Translated by Ford Lewis Battles (Westminster John Knox Press).

Clines, D. J. A. 1968. “The Image of God in Man." Tyndale Bulletin 19: 53-103.

Darwin, Charles. 2003. On the Origin of Species. Edited by Joseph Carroll (Broadview Press).

Darwin, Charles. 2004. The Descent of Man (Penguin).

Geach, Peter. 2001. Truth and Hope (University of Notre Dame Press).

Hoekema, Anthony. 1986. Created in God's Image (Eerdmans).

Irenaeus. 1992. Against the Heresies. Translated by Dominic J. Unger (Paulist Press). Li, Norman P., and Satoshi Kanazawa. 2016. "Country Roads, Take Me Home ... To My Friends." British Journal of Psychology 107: 675-697. https://doi.org/10.1111/bjop.12181

Matchulat, Justin. 2015. "Rationality and Human Value." Faith and Philosophy 32: 404-422. https://doi.org/10.5840/faithphil201510150

\footnotetext{
${ }^{69}$ I want to thank James Collin, Kyle Scott, Donald Smith, James Watkins, Tyron Goldschmidt, and Duncan Pritchard for their helpful comments on various drafts of this paper. I also want to thank the editor of this journal and an anonymous referee for their insightful and helpful comments.
} 
McDonald, Nathan. 2008. "The Imago Dei and Election." International Journal of Systematic Theology 10: 303-327. https://doi.org/10.1111/j.1468-2400.2008.00283.x Middleton, J. Richard. 2005. The Liberating Image (Brazos Press).

Moore, Alan. 1995. Watchmen (DC Comics).

Morgan, T. J. H., N. T. Uomini, L. E. Rendell, L. Chouinard-Thuly, S. E. Street, H. M. Lewis, C. P. Cross, C. Evans, R. Kearney, I. de la Torre, A. Whiten, and K. N. Laland. 2015. "Experimental Evidence for the Co-Evolution of Hominin ToolMaking Teaching and Language." Nature Communications 6: 1-8. https://doi.org/10.1038/ncomms7029

Moritz, Joshua. 2011. "Evolution, the End of Human Uniqueness, and the Election of the Imago Dei." Theology and Science 9: 307-339. https://doi.org/10.1080/14746700.2011.587665

Pritchard, Duncan. 2010a. "Achievements, Luck, and Value." Thought 10: 19-30. https://doi.org/10.1017/S1477175610000035

Pritchard, Duncan. 2010b. "Knowledge and Final Value." In The Nature and Value of Knowledge, edited by Duncan Pritchard, Alan Millar, and Adrian Haddock (Oxford University Press), 37-66.

https://doi.org/10.1093/acprof:oso/9780199586264.003.0002

Rachels, James. 1990. Created from Animals (Oxford University Press).

Rad, Gehard von. 1972. Genesis: A Commentary. Translated by John H. Marks (Westminster Press).

Rosenberg, Alex, and Daniel W. McShea. 2012. Philosophy of Biology (Routledge).

Sarna, Nahum. 2001. JPS Torah Commentary: Genesis (The Jewish Publication Society).

Sawyer, J., Victor Deak, Esteban Sarmiento, Mary Leakey, Ian Tattersall, and Richard Milner. 2007. The Last Human (Yale University Press).

Simpson, G. G. 1950. Meaning of Evolution (Yale University Press).

Stek, John H. 1990. "What Says the Scripture?" In Portraits of Creation, edited by Howard Van Till, Robert E. Snow, John H. Stek, and Davis A. Young (Eerdmans), 232-242.

Stewart, J. R., and C. B. Stringer. 2012. "Human Evolution Out of Africa." Science 335: 1317-1321. https://doi.org/10.1126/science.1215627

Watkins, James M. 2015. Creativity and Sacrifice (Fortress Press). https://doi.org/10.2307/j.ctt9m0t32 